\title{
Cross-talk between HIF and p53 as mediators of molecular responses to physiological and genotoxic stresses
}

\author{
Joanna Obacz ${ }^{1,2}$, Silvia Pastorekova ${ }^{2}$, Borek Vojtesek ${ }^{1}$ and Roman Hrstka ${ }^{\text {* }}$
}

\begin{abstract}
Abnormal rates of growth together with metastatic potential and lack of susceptibility to cellular signals leading to apoptosis are widely investigated characteristics of tumors that develop via genetic or epigenetic mechanisms. Moreover, in the growing tumor, cells are exposed to insufficient nutrient supply, low oxygen availability (hypoxia) and/or reactive oxygen species. These physiological stresses force them to switch into more adaptable and aggressive phenotypes. This paper summarizes the role of two key mediators of cellular stress responses, namely p53 and HIF, which significantly affect cancer progression and compromise treatment outcomes. Furthermore, it describes cross-talk between these factors.
\end{abstract}

Keywords: p53, HIF-1, Hypoxia, DNA damage, Cancer

\section{HIF-mediated responses to hypoxia}

Important consequences of rapid tumor growth include poor vascularization and insufficient oxygen delivery that together lead to formation of hypoxic (poorly oxygenated) areas [1]. Adaptation to hypoxia is facilitated by the activation of transcriptional machinery, in which hypoxia inducible factor (HIF) plays a pivotal role. HIF is a heterodimeric transcription factor composed of an oxygendependent $\alpha$-subunit and constitutively expressed $\beta$ subunit. Regulation of the $\alpha$-subunit is driven by enzymes of the prolyl hydroxylase family (PHDs) and by the factor inhibiting HIF (FIH) [2,3]. Under normoxia, PHDs hydroxylate prolines at positions 564 and 402 (in HIF-1 $\alpha$ isoform) and FIH hydroxylates asparagine at position 803 [3]. Hydroxylation of prolines is required for recognition of HIF$1 \alpha$ by the ubiquitin ligase complex via von Hippel-Lindau (pVHL) tumor suppressor protein, which in consequence leads to HIF- $1 \alpha$ ubiquitination followed by its proteasomal degradation [2]. Simultaneously, FIH prevents interaction between HIF- $1 \alpha$ and the transcriptional co-activator, p300. Although there are three isoforms of the $\alpha$-subunit: HIF$1 \alpha$, HIF- $2 \alpha$ and HIF- $3 \alpha$, most attention is drawn to HIF- $1 \alpha$

\footnotetext{
* Correspondence: hrstka@mou.cz

${ }^{1}$ Masaryk Memorial Cancer Institute, Regional Centre for Applied Molecular Oncology, Zluty kopec 7, 65653 Brno, Czech Republic

Full list of author information is available at the end of the article
}

and HIF-2 $\alpha$. These subunits contain similar oxygendependent degradation domains, but play different roles in hypoxic tumor growth and progression (for extended review see Keith et al.) [4]. Whereas HIF-1 mediates acute responses to hypoxia, HIF-2 is more involved in adaptation to chronic hypoxia and is functionally implicated in tumor progression [5].

In situations of insufficient oxygen levels, PHDs and FIH remain inactive, while HIF- $1 \alpha$ is no longer hydroxylated and escapes recognition by pVHL. This results in its stabilization, accumulation and translocation to the nucleus, where it interacts with a $\beta$-subunit leading to creation of an active heterodimeric form of the transcription factor. This heterodimer binds to specific cisacting hypoxia responsive elements (HREs) in the promoters of target genes [6].

Several recent reports point out novel molecular mechanisms that affect HIF- $1 \alpha$ levels in normoxia. An inhibitor of Janus Activated Kinase (JAK2), AG490, prevents HIF- $1 \alpha$ hydroxylation and thus interferes with VHL-mediated degradation resulting in increased HIF$1 \alpha$ protein half-life [7]. Another mechanism by which HIF- $1 \alpha$ can be rescued from degradation is via interaction with ubiquitin-specific protease 19 (USP19) [8]. Epigenetic mechanisms such as histone methylation can also be involved in HIF-1 $\alpha$ regulation, which was studied 
in clear cell renal cell carcinoma (ccRCC) [9]. Moreover, HIF-1 activity is phosphorylation-dependent and thus requires engagement of signaling such as mitogenactivated protein kinase (MAPK), PI3K/Akt and mammalian target of rapamycin (mTOR), amongst others (see review by Dimova et al.) [10].

HIF-induced cascades of events allow cells to survive and overcome unfavorable conditions during hypoxia by transcriptional reprogramming that leads to modulated proliferation, angiogenesis, cell metabolism and many other features of tumor phenotype. One of the prominent HIF-1 downstream genes involved in this process is the gene coding for carbonic anhydrase IX (CA IX). CA IX is a member of the family of zinc metalloenzymes involved in regulation of cellular $\mathrm{pH}$ by reversible conversion of $\mathrm{CO}_{2}$ to bicarbonate and proton [11,12]. Its activity is regulated by hypoxia through protein kinase $\mathrm{A}$ and leads to acidosis of the tumor milieu, which is known to be one of the hallmarks of solid tumors $[13,14]$. CA IX also promotes tumor cell growth and survival and helps to eliminate the surplus of intracellular acids generated through oncogenic metabolism $[15,16]$. Moreover, it facilitates migration and invasiveness of tumor cells and thereby supports tumor progression [17].

To satisfy the need for nutrients, tumor cells are forced to create an extensive net of new vessels through increased expression of pro-angiogenic molecules, including vascular endothelial growth factor (VEGF), which is also a well-known HIF target gene [18,19]. Additionally, VEGF can promote both angiogenesis and metastasis via up-regulation of matrix metalloproteinase 28 and matrix metalloproteinase 14 [20].

Due to lack of oxygen, a key factor for respiration, hypoxia is also known to induce a shift to glycolytic metabolism [21]. HIF-1 plays a growth factor-dependent role in the regulation of glycolysis in hematopoietic cells even in the absence of hypoxia [22] and reduces mitochondrial respiration in RCC lacking VHL [23]. HIF was also shown to be responsible for expression of specific isoforms of glycolytic enzymes and transporters via alternative splicing [24].

There are many other molecular targets of HIF that execute multiple adaptive responses to hypoxia depending on the cell type and physiological context as described elsewhere $[25,26]$.

\section{p53-mediated responses to genotoxic stress}

Tumor suppressor $\mathrm{p} 53$, which shows many similarities to HIF-1 in terms of protein control by degradation, is predominantly involved in adaptation of cells to genotoxic stresses. p53 is a well-characterized transcription factor that plays a crucial role in responses to DNA damage, aberrant cell cycle control, apoptosis, and senescence [27-29]. Comparably to HIF-1 $\alpha$, the basal level of wild-type p53 is kept low due to murine double minute 2 (MDM2)-dependent ubiquitination [30]. In response to DNA damage p53 is stabilized and phosphorylated by ataxia telangiectasia mutated (ATM) protein, which leads to its activation and binding to the regulatory region of target genes [31,32]. Moreover, p53 can be regulated through methylation caused by MDM2dependent recruitment of methyltransferases [32]. In contrast, MDM2 can also act as a p53 inducer. This is mediated through the interaction of p53 mRNA region containing the MDM2-binding site with the RING domain of MDM2, which impairs the E3 ligase activity of MDM2 and promotes p53 mRNA translation [33]. This interaction depends on ATM-mediated phosphorylation of MDM2 at Ser395 [34]. Finally, activated p53 can then start the machinery leading either to cell cycle arrest and DNA repair or to apoptosis. For example, p53dependent upregulation of genes involved in inhibition of IGF-1/AKT and mTOR pathways prevents cell growth and division $[29,35,36]$. On the other hand, inhibition of DNA damage-activated kinases leads to switch of the p53-dependent growth arrest to apoptosis [37].

ATF3 gene, a downstream target of p53, encodes a transcription factor involved in adaptation to hypoxia, ER stress, oxidative stress and genotoxic stress [38]. ATF3 acts both as an effector of p53-mediated cell death and a regulator of p53 signaling. A recent report indicates that ATF3 has opposing effects on apoptotic transcriptome in stress response and in cancer, where it was found to be over-expressed [39]. Zhang and colleagues [40] developed a four-module model to investigate p53 dynamics and the DNA damage response. They found that primary modifications such as phosphorylation at Ser-15 and Ser-20 cause cell cycle arrest, whereas further modifications such as phosphorylation at Ser-46 fully activate p53 which can then induce apoptosis. This report more clearly elucidates how p53 converts between the cell cycle arrester and the killer, which was previously shown to be controlled by Wip1 (wild-type p53-induced phosphatase 1) [41].

p53 does not only act as a transcriptional factor in the nucleus, but also can move to the mitochondria where it induces permeabilization of the mitochondrial outer membrane consequently releasing pro-apoptotic factors [28]. Suppression of autophagy via inhibition of AMPdependent kinase and/or activation of mTOR is another cytoplasmic p53 function [42]. For the extensive insight into the cytoplasmic functions of p53, see the review by Green and Kroemer [28].

p53 as a tumor suppressor plays an important role in maintaining of genome stability thus it is not surprising that is mutated in more than $50 \%$ of cancers in which its loss facilitates malignant transformation [43]. The 
majority of p53 mutations represent missense mutations located in the DNA-binding core domain of p53, producing a full-length protein that is incapable of binding DNA and is therefore nonfunctional as a transcriptional activator/repressor. Compared to wild-type p53, missense mutant proteins show increased stability, which is partly caused by their inability to induce MDM2 but also by the formation of complexes with HSP90 and HSP70 [44].

\section{Cross-talk between HIF-1 and p53}

In addition, p53 participates in responses to hypoxia by regulating expression of genes involved in cell cycle control. This happens via a pathway that is different than that involved in the DNA damage response [45]. There are many contradictory reports on mutual influence of p53 and hypoxic signaling. Some of them claim that hypoxia causes accumulation and increase in $\mathrm{p} 53$ protein level $[46,47]$, whereas others postulate degradationmediated decrease in p53 level $[48,49]$ or no effect at all [50]. These intricate relations have been extensively reviewed by Sermeus and Michiels [51]. One explanation of these contradictory statements can be found in the phosphorylation status of HIF-1. It was shown that dephosphorylated HIF-1 is a major form binding to p53, precluding downregulation of $\mathrm{p} 53$ by MDM-2, and thus enabling it to conduct apoptosis [52]. As both p53 and HIF-1 are mediators of cell adaptation to many stresses, they are known to be involved in similar processes such as apoptosis, cell cycle control, metabolism etc. (Figure 1). Severe and/or prolonged hypoxia activates p53-dependent apoptosis, which is initiated by stabilization of 53 by HIF-1 [53]. In contrast, another report states that hypoxia causes growth arrest by decreasing p53 phosphorylation, but has no impact on either p $21^{\text {WAF1 }}$ or HIF-1 protein stabilization [54]. One of the possible explanations is that these convergences can be due to cancer cell type [55]. Opposite effects can be observed upon genotoxic stress, where wild-type 53 abrogates HIF-1 activity triggering its proteasomal degradation [56].

However, there is a line of evidence that HIF-1 can also impair p53 activity, through the downregulation of the tumor suppressor homeodomain-interacting protein kinase-2 (HIPK2) [57]. HIPK2 phosphorylates p53 at serine 46 in response to DNA damage and subsequently activates its apoptotic function [58]. Moreover, HIPK2 inhibition can result from the hypoxia-induced upregulation of MDM2 [59].

p53 can respond to DNA damage in cooperation with $70 \mathrm{kDa}$ subunit of the replication protein A (RPA70). Under hypoxia, wild-type p53 undergoes a conformational change and acquires mutant conformation [60]. Furthermore, hypoxia leads to disruption of the complex between p53 and RPA70, dissociation of RPA70 and activation of RPA70-mediated nucleotide excision repair and non-homologous end-joining repair, which cause resistance to apoptosis in hypoxic cancer cells [61]. That report poses a new insight into impairment of the p53mediated apoptosis and consequent insensitivity of cancer cells to treatment. However, it is still hard to elucidate what starts the p53 and/or HIF-1 machinery for the adaptation of cells to unfavorable conditions.

Thomas et al. [62] focused on tumor response to nitric oxide (NO) exposure and proposed that both p53 and HIF-1 are stabilized by NO in a dose- and timedependent manner, with a higher NO concentration required for p53 stabilization. They suggested that cells localized closer to the source of NO production can undergo p53-dependent cell arrest and death, while more distant cells respond with increased HIF-1 levels. Additionally, their results indicated that HIF-1 stabilization by $\mathrm{NO}$ was independent of p53 status.

Altered metabolism is one of the prominent features that promote tumor survival. The first who discovered that tumors rely on anaerobic glycolysis even in the presence of sufficient oxygen and produce large amount of lactate was Otto Warburg [63]. Later this phenomenon was named after him. The consequences of this effect have been previously reviewed [64]. Another tumor characteristic is increased uptake of nutrients that as stated by Vander Heiden et al. [65] is due to oncogenic mutations mainly in Akt, Myc and Ras [66]. A multitude of mutations of genes encoding enzymes participating in glycolysis, tricarboxylic acid cycle, mitochondrial oxidative phosphorylation and other molecular pathways underlying the advantageous metabolism of cancers have been already characterized [67-71]. Comprehensive insights into this phenomenon can be found in recent works [72-75]. In this respect HIF-1 and p53 play crucial, but usually competing, roles. HIF-1 controls expression of genes encoding e.g. glucose transporters, glycolytic enzymes, lactate dehydrogenase etc. [25,76]. Interestingly, inactivating mutations in fumarate hydratase and succinate dehydrogenase cause accumulation of their substrates, which interfere with HIF- $1 \alpha$ degradation leading to its accumulation [77]. On the other hand, loss of p53 contributes to enhancement of glucose transport and metabolism through NF- $\mathrm{kB}$ pathway [78]. Furthermore, it increases lactate production, diminishes oxygen consumption and enhances hypoxia-induced cell death. Disruption of p53 function reduces the expression of cytochrome c oxidase 2 (SCO2), which is necessary for the respiratory chain function [79]. This indicates that mutations in the TP53 gene contribute to Warburg effect.

In order to eliminate damaged proteins and organelles as well as to fulfill requirements for high ATP level, 


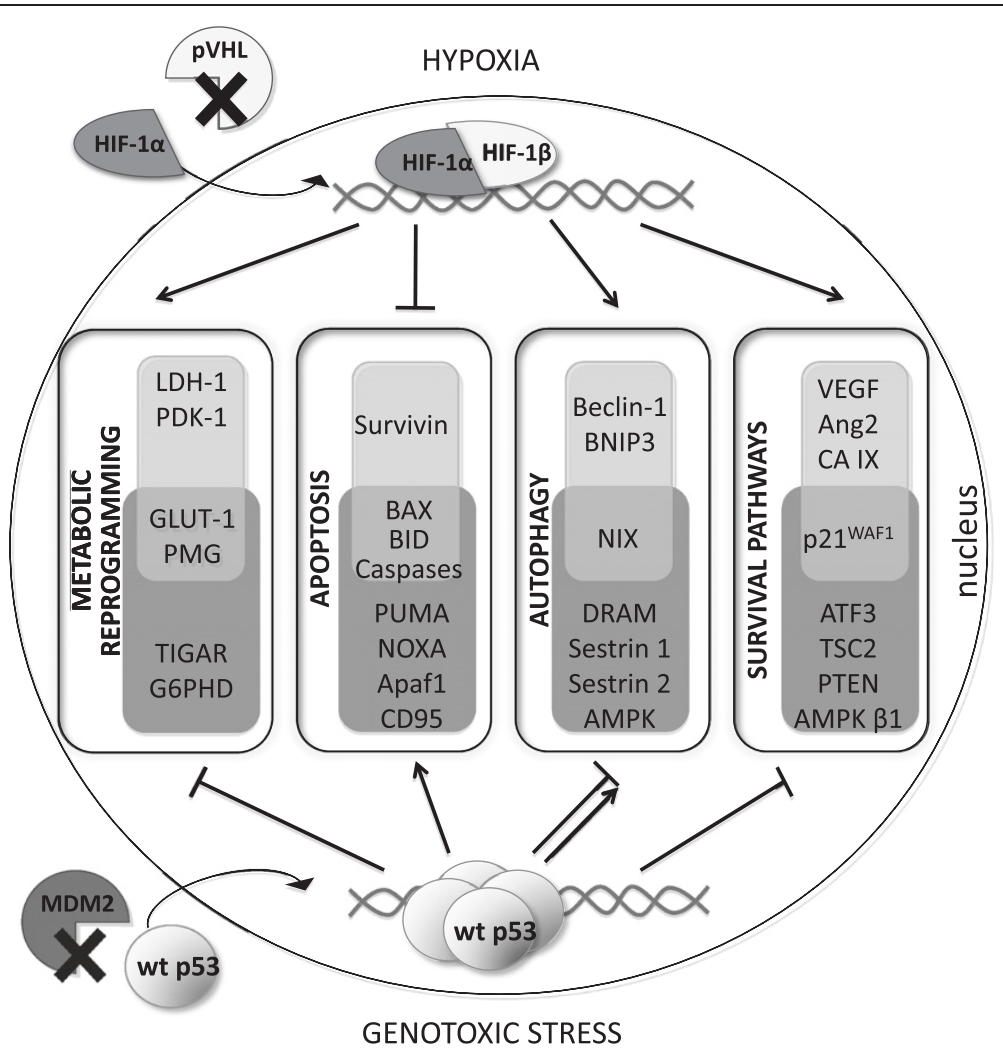

Figure 1 HIF-1 and/or p53 regulated genes mediating adaptation to cellular stresses through activation of different pathways. Upon hypoxia, the interaction between HIF-1a and von Hippel Lindau protein (pVHL) is disrupted, leading to HIF-1a translocation into nucleus, dimerization with HIF-1 $\beta$ subunit and formation of HIF-1 active form, which can regulate transcription of target genes. HIF-1 activates lactate dehydrogenase (LDH-A), pyruvate dehydrogenase kinase 1 (PDK1), phosphoglycerate mutase (PGM) and glucose transporter 1 (GLUT-1) to switch into more glycolytic phenotype [25]. To prevent apoptosis, it induces survivin expression [25] and downregulates BAX, BID and caspases activity [26]. HIF-1 can also induce autophagy by upregulation of beclin-1, BNIP3 and NIX [81]. Through modulating vascular endothelial growth factor (VEGF) [18], angiopioetin-2 (Ang-2) [25], carbonic anhydrase IX (CA IX) [12] and p21 WAF1 [90] expression, HIF-1 triggers activation of pro-survival pathways. Different molecular stresses (including DNA damage, hypoxia, oxidative stress), cause dissociation of p53 from murine double minute 2 (MDM2) complex, enabling its binding to regulatory elements of target genes [31]. Thereby p53 can repress glycolysis by altering expression of GLUT-1, PGM, TP53-induced glycolysis and apoptosis regulator (TIGAR) and inhibits pentose phosphate pathway by downregulating glucose-6 -phosphate dehydrogenase (G6PDH) [36]. p53 regulates expression of many pro-apoptotic proteins, including PUMA, NOXA, CD95, Apaf1, BAX, BID and caspases [28]. Induction of autophagy by p53 relies on activation of damage-regulated autophagy modulator (DRAM) [83], sestrin 1, sestrin 2 and AMP-dependent kinase (AMPK) [84], but depending on cellular localization it can also inhibit this process [86]. Regulation the expression of transcription factor ATF3 enables adaptation to hypoxia, ER stress, oxidative stress and genotoxic stress [38], whereas during hypoxia induction of p21 ${ }^{\text {WAF1 }}$ causes cell cycle arrest [102]. p53 suppresses Akt-mTOR axis by transactivation of PTEN, TSC2 and AMPKB1 [36].

cancer cells utilize the machinery of autophagy, a catabolic process in which cytoplasmic cargos are embedded in double-membrane structures called autophagosomes to digest their content [80]. Among proteins involved in triggering autophagy, BCL2/adenovirus E1B 19kDainteracting protein 3 (BNIP3), BCL2/Adenovirus E1B $19 \mathrm{kDa}$ Interacting Protein 3-Like (BNIP3L, NIX), together with Beclin-1 are induced under hypoxia in HIF1-dependent manner (see review by Mazure and Pouyssegur) [81]. Moreover, HIF-1 promotes the proautophagic signaling pathways in adjacent tumor stroma, which not only provides cancer cells with necessary chemical building blocks but also renders them less susceptible to apoptosis [82]. p53 involvement in autophagy appears to rely on two contradictory functions. On one hand, p53 facilitates autophagy by inducing expression of a damage-regulated autophagy modulator (DRAM) [83], sestrin 1, sestrin 2, AMP-dependent kinase (AMPK) [84] and/or inhibiting mTOR pathway [85]. On the other, Tasdemir et al. [86] postulate that cytoplasmic fraction of p53 can repress autophagy through a transcription-independent effect and that p53 inactivation enhances this process. On the contrary, Naves et al. [87] found that neuroblastoma cells with the mutated p53 undergo autophagy when exposed to hypoxia mimetic $\mathrm{CoCl}_{2}$, but this pathway is activated when p53 localizes to the nucleus. The studies quoted above show that the 'self-digestion' is another 
example of the mutual communication between HIF-1 and p53 in regulation of the tumor cells survival.

Recent developments in the field of senescence, a process leading to elimination of damaged cells from the growing population and subsequently preventing cancer occurrence, reveal a dual role for hypoxia. Leontieva et al. [88] found that hypoxia inhibits a conversion from the reversible cell cycle arrest to senescence (known as geroconversion), nutlin-induced senescence and mTOR activity. Additionally, in marrow-derived mesenchymal stem cells (MSCs) hypoxia promotes proliferation [89] and causes downregulation of $\mathrm{p} 21^{\mathrm{WAF} 1}$ expression in a HIF-1 $\alpha$-dependent manner [90]. On the other hand, many of HIF-1- regulated genes are associated with the senescence induction, including plasminogen activator inhibitor (PAI1), cell cycle regulators, glycolytic enzymes and secreted molecules (see review by Welford et al.) [91]. The classic model of senescence shows that hyperoxia can induce senescence through reactive oxygen species (ROS). In accordance, senescence is inhibited under low oxygen conditions simply due to decreased production of the mitochondrial ROS [92]. Interestingly, recent report indicates that overexpression of caveolin-1 in the cancer-associated fibroblasts causes induction of their senescence and supports tumor growth due to HIF-1 $\alpha$ stabilization by ROS increase [93]. In addition, VHL loss induces senescence in an oxygen-dependent manner by increasing the level of p27, which regulates cell cycle. However, these effects do not rely on HIF- $1 \alpha$ or HIF- $2 \alpha$ activity [94]. p53 involvement in senescence has been intensively studied till nowadays and recent achievements in that field have been profoundly reviewed [95-97]. It is noteworthy that p53 induction together with the prolonged p $21^{\text {WAF1 }}$ overexpression can suppress senescence in favor of quiescence [98].

Importantly, the cross-talk between p53 and HIF-1 can be observed at the level of their regulation, within a complex molecular loop which involves both factors (Figure 2). As mentioned before, ATM mediates a DNA double strand break signaling and repair via phosphorylation of p53. Ousset et al. [99] used various cellular models where ATM was disrupted and demonstrated that the absence of ATM increases expression of both subunits of HIF-1 as well as protein biosynthesis, through oxidative stress. However, ATM is also responsible for the

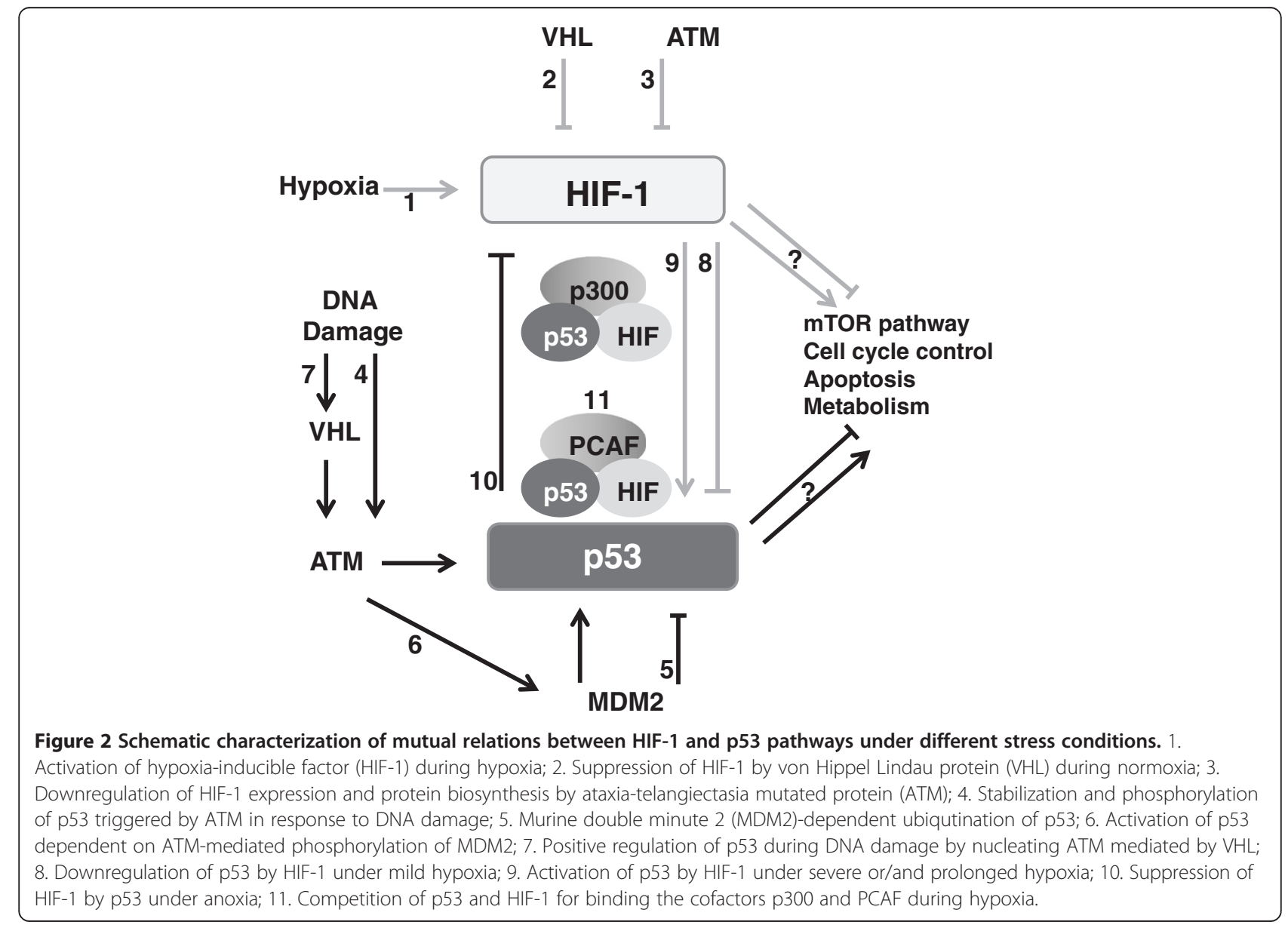


phosphorylation of HIF-1 on Ser-696, which causes a downregulation of $\mathrm{mTORC1}$ signaling that regulates a translational efficiency [100]. Not only hypoxia suppresses the mTOR pathway; $\mathrm{p} 53$ in response to stress also negatively regulates $\mathrm{mTORC} 1$ by inducing the expression of a plethora of target genes in the IGF-1/AKT and mTOR pathways. This intrinsic regulation was reviewed previously [29].

Another crosstalk between HIF-1 and p53 is observed on the level of trans-activation. During hypoxia, these transcription factors compete for the binding to the $\mathrm{CH} 1$ domain of p300 cofactor [101]. Furthermore, it was found that another cofactor, p300/CBP Associated Factor (PCAF) is involved in this regulatory mechanism. A study carried out by Xenaki et al. [102] focused on the expression of the pro-apoptotic p53 target BID and revealed a molecular mechanism underlying the regulation of p53 transcriptional activity in hypoxia. They have shown that hypoxia not only enables preferential direction of $\mathrm{p} 53$ to the promoter of $\mathrm{p} 21^{\mathrm{WAF} 1}$ cell cycle arrester via PCAF, but also decreases PCAF-dependent acetylation of $\mathrm{p} 53$, which disrupts binding to its proapoptotic targets. They found that PCAF is also a HIF-1 cofactor involved in HIF-1- mediated apoptosis, whereas PCAF histone acetyltransferase (HAT) activity regulates transcriptional selectivity.

Additional convergences are visible on the level of regulation of these two transcription factors by VHL, which as mentioned above, is a well-documented ubiquitin-dependent executer of HIF-1 degradation $[2,103]$. However, it was also reported that VHL positively regulates p53 activity, preceded by DNA damage, via nucleating ATM and histone acetyltransferase to p53. It also influences cell cycle arrest and apoptosis triggered by p53 due to upgrading the p53-p300 interaction and p53 acetylation [103]. Moreover, ATF3 links the molecular pathways of HIF-1 and p53 in response to DNA-damage, where both transcription factors are overrepresented, which can be explained by the suggestion that ATF3 synergizes with these transcription factors to modulate their target gene expression [39]. Recently, FIH was added to an even more complicated network in which p53 and HIF-1 are involved: FIH silencing in colon adenocarcinomas and melanoma cells greatly abolishes cell proliferation and, more importantly, increases both p53 and p21 WAF1 protein levels [104]. These results support the role of FIH in the suppression of the p53-p21 WAF1 axis.

\section{Impact of the p53 and HIF-1 interplay on cancer progression}

Despite the fact that p53 is known to prevent mutations which cause genome instability and can lead to carcinogenesis, it represents one of the most frequently mutated genes in solid tumors [45]. Conformational changes related to missense mutations in the DNA-binding domain disrupt p53 transcriptional activity resulting in impaired ability of p53 to regulate the cellular response to hypoxia in an effective way $[105,106]$. It was also established that low oxygen pressure selects cells carrying p53 mutation and due to that contributes to metastatic potential and diminished apoptosis [46,107]. Interestingly, Gogna et al. [60] using in-vivo electron paramagnetic resonance oximetry 3D imaging found that conformationally mutated p53 appears in tumor hypoxic core and that its conformation is oxygen-dependent.

Furthermore, not only p53 mutations act in favor of cancer progression. Also hypoxia correlates with more aggressive tumor phenotypes and poor responses to therapy [108]. This mainly involves stabilization of HIF1 and overexpression of its target genes [109]. For instance, expression of a HIF-1 target CA IX has been investigated in various types of cancers, including breast, colorectal, pancreatic etc. [110-112]. In these reports overexpression of this hypoxic marker was associated with poorer patient survival, less differentiated tumors of higher grade and worse response to therapy. Similar effects were described for VEGF in lung and gastric cancers [20,113]. Interestingly, high expression of HIF hydroxylases, which negatively regulate HIF-1 and are themselves regulated by hypoxia were postulated as poor prognostic factors in non small cell type lung cancers [114], whereas their inhibition reduced survival of glioblastoma cells [115]. Concurrent overexpression of both HIF-1 and p53 was found in many cancers as well [116]. An in vivo study, based on an experimental model of chick embryo chorioallantoic membrane, revealed that HIF- $1 \alpha$ increases invasiveness of human small cell lung carcinoma via promoting angiogenesis not only due to overexpression of VEGF but also due to secretion of pro-inflammatory factors [20]. Moreover, Khromova et al. [117] found that accelerated growth of cancer cells is associated with p53 mutations and caused by ROSmediated activation of the HIF-1/VEGF-A pathway, which links both factors with neovascularization. In a large cohort of colorectal cancers, HIF-1 $\alpha$ but not HIF$2 \alpha$ was shown to have an important negative prognostic role in cancer aggressiveness and overall survival of patients [118]. Contradictory to that, Cleven et al. [110] suggested that in the stroma of these tumors HIF-2 $\alpha$ and CA IX serve as poor prognostic factors in tumors expressing wild-type p53 compared with tumors with mutant form. Regarding p53, some studies join its expression with patient survival [119] another with invasion depth [120] and poor differentiation [111] or worse distant survival [121]. Moreover, another report indicates no significant survival difference between wild-type and mutant p53 [110]. This leaves an open question on how 
hypoxia selects for mutated p53 and thereby impacts on patient outcome.

Hypoxia causes resistance to commonly used anticancer agents either due to downregulation of genes that are drug targets or because oxygen deprivation abrogates activity of the drugs. Chemotherapeutics of the first choice (doxorubicin, etoposide, cisplatin) cause DNA damage and therefore activate p53 to conduct apoptosis. HIF-1 by modulating expression of its target genes, render the cells less prone to treatment, although this effect is cell type-dependent [55]. Insensitivity can be HIF-1 independent as well, but relies on p53 suppression [122]. Moreover, hypoxic cells divide less rapidly and are localized further from functional blood vessels. Due to that, drugs are unable to reach poorly oxygenated areas and work less efficiently than in highly proliferating cells [123].

Last but not least, overexpression of P-glycoprotein (Pgp), a member of ATP-binding cassette (ABC) protein superfamily has been reported to cause multidrug resistance (MDR) of tumors [124,125]. Other studies elucidated that increase in Pgp abundance is due to transactivation by HIF- 1 recruited to the MDR- 1 gene in MCF-7 spheroids and hypoxic cells. Importantly, both MCF-7 spheroids and hypoxic cells show lower susceptibility to doxorubicin treatment and reduced accumulation of drugs [126].

\section{Conclusions}

It is well known that hypoxia and genome instability are intrinsic tumor characteristics, which influence cancer progression and hence patient outcome. This report describes mutual relations between p53 and HIF-1 as mediators of adaptation to diverse cellular stresses, including DNA damage and hypoxia. Although they share many similarities, they can either act in parallel or compete with each other in regulation of diverse molecular pathways. These discrepancies have been extensively studied, but there are still many gaps in understanding what triggers pro-survival or lethal activity of these transcription factors. This work highlights the importance of further investigation of this loop as the data mentioned above indicate that it involves both positive and negative regulators as well as epigenetic mechanisms. This knowledge is indispensable not only for proper patient treatment, which as reported here can be influenced by both cancer cell type and tumor environment, but also for development of new drugs targeting $\mathrm{p} 53$ and/or HIF-1 pathways.

\section{Abbreviations}

ABC: ATP-binding cassette protein superfamily; ATM: Ataxia telangiectasia mutated protein; BNIP3: BCL2/adenovirus E1B 19kDa-interacting protein 3; BNIP3L: BCL2/Adenovirus E1B 19kDa Interacting Protein 3-Like; CA

IX: Carbonic anhydrase IX; DRAM: Damage-regulated autophagy modulator;
FIH: The factor inhibiting HIF; HIF: hypoxia inducible factor; HIPK2: Homeodomein-interacting protein kinase-2; HREs: Hypoxia responsive elements; JAK2: Janus Activated Kinase; MAPK: Mitogen-activated protein kinase; MDM2: Murine double minute 2; MDR: Multidrug resistance;

MSCs: Marrow-derived mesenchymal stem cells; mTOR: mammalian target of rapamycin; NO: Nitric oxide; PAl1: Plasminogen activator inhibitor; PCAF: p300/CBP Associated Factor; PHDs: Prolyl hydroxylase family; Pgp: Pglycoprotein; $\mathrm{PVHL}$ : Von Hippel-Lindau tumor suppressor protein; ROS: Reactive oxygen species; RPA70: $70 \mathrm{kDa}$ subunit of replication protein A; SCO2: Cytochrome c oxidase 2; USP19: Ubiquitin-specific protease 19; Wip1: Wild-type p53-induced phosphatase 1; VEGF: Vascular endothelial growth factor.

\section{Competing interests}

The authors declare they have no competing interests.

\section{Authors' contributions}

JO reviewed the literature, and wrote and edited the manuscript. SP contributed to study conception and critically revised the paper. BV critically revised the paper. $\mathrm{RH}$ contributed to study conception, revised and finalized the manuscript. All authors read and approved the final manuscript.

\section{Acknowledgements}

This work was supported by the European Regional Development Fund and the State Budget of the Czech Republic RECAMO CZ.1.05/2.1.00/03.0101, MH CZ-DRO (MMCl, 00209805), GACR P206/12/G151, GACR P301/13/00956S and by the $7^{\text {th }}$ Framework Program (ITN project ENGCABRA).

\section{Author details}

${ }^{1}$ Masaryk Memorial Cancer Institute, Regional Centre for Applied Molecular Oncology, Zluty kopec 7, 65653 Brno, Czech Republic. ${ }^{2}$ Department of Molecular Medicine, Institute of Virology, Slovak Academy of Sciences, Dubravska cesta 9, 84505 Bratislava, Slovak Republic.

Received: 23 April 2013 Accepted: 10 August 2013

Published: 14 August 2013

\section{References}

1. Liao D, Johnson RS: Hypoxia: a key regulator of angiogenesis in cancer. Cancer Metastasis Rev 2007, 26(2):281-290.

2. Ivan M, Kondo K, Yang H, Kim W, Valiando J, Ohh M, Salic A, Asara JM, Lane WS, Kaelin WG Jr: HIFalpha targeted for VHL-mediated destruction by proline hydroxylation: implications for $\mathrm{O} 2$ sensing. Science 2001, 292(5516):464-468.

3. Lando D, Peet DJ, Gorman JJ, Whelan DA, Whitelaw ML, Bruick RK: FIH-1 is an asparaginyl hydroxylase enzyme that regulates the transcriptional activity of hypoxia-inducible factor. Genes Dev 2002, 16(12):1466-1471.

4. Keith B, Johnson RS, Simon MC: HIF1a and HIF2a: sibling rivalry in hypoxic tumour growth and progression. Nat Rev Cancer 2012, 12(1):9-22.

5. Uchida T, Rossignol F, Matthay MA, Mounier R, Couette S, Clottes E, Clerici $\mathrm{C}$ : Prolonged hypoxia differentially regulates hypoxia-inducible factor (HIF)-1alpha and HIF-2alpha expression in lung epithelial cells: implication of natural antisense HIF-1alpha. J Biol Chem 2004, 279(15):14871-14878.

6. Ratcliffe PJ, O'Rourke JF, Maxwell PH, Pugh CW: Oxygen sensing, hypoxiainducible factor-1 and the regulation of mammalian gene expression. J Exp Biol 1998, 201(Pt 8):1153-1162.

7. Fernandez-Sanchez R, Berzal S, Sanchez-Nino MD, Neria F, Goncalves S, Calabia O, Tejedor A, Calzada MJ, Caramelo C, Deudero JJ, et al: AG490 Promotes HIF-1alpha accumulation by inhibiting its hydroxylation. Curr Med Chem 2012, 19(23):4014-4023.

8. Altun M, Zhao B, Velasco K, Liu H, Hassink G, Paschke J, Pereira T, Lindsten K: Ubiquitin-specific protease 19 (USP19) regulates hypoxia-inducible factor 1a (HIF-1a) during hypoxia. J Biol Chem 2012, 287(3):1962-1969.

9. Xu J, Wang B, Xu Y, Sun L, Tian W, Shukla D, Barod R, Grillari J, GrillariVoglauer $\mathrm{R}$, Maxwell PH, et al: Epigenetic regulation of HIF-1a in renal cancer cells involves HIF-1a/2a binding to a reverse hypoxia-response element. Oncogene 2012, 31(8):1065-1072.

10. Dimova EY, Michiels $C$, Kietzmann T: Kinases as upstream regulators of the HIF system: their emerging potential as anti-cancer drug targets. Curr Pharm Des 2009, 15(33):3867-3877. 
11. Pastorek J, Pastorekova S, Callebaut I, Mornon JP, Zelnik V, Opavsky R, Zat'ovicova M, Liao S, Portetelle D, Stanbridge EJ, et al: Cloning and characterization of $\mathrm{MN}$, a human tumor-associated protein with a domain homologous to carbonic anhydrase and a putative helix-loop -helix DNA binding segment. Oncogene 1994, 9(10):2877-2888.

12. Wykoff CC, Beasley NJ, Watson PH, Turner KJ, Pastorek J, Sibtain A, Wilson GD, Turley H, Talks KL, Maxwell PH, et al: Hypoxia-inducible expression of tumor-associated carbonic anhydrases. Cancer Res 2000, 60(24):7075-7083.

13. Ditte $P$, Dequiedt F, Svastova E, Hulikova A, Ohradanova-Repic A, Zatovicova M, Csaderova L, Kopacek J, Supuran CT, Pastorekova S, et al: Phosphorylation of carbonic anhydrase IX controls its ability to mediate extracellular acidification in hypoxic tumors. Cancer Res 2011, 71(24):7558-7567.

14. Svastova E, Hulikova A, Rafajova M, Zat'ovicova M, Gibadulinova A, Casini A, Cecchi A, Scozzafava A, Supuran CT, Pastorek J, et al: Hypoxia activates the capacity of tumor-associated carbonic anhydrase IX to acidify extracellular pH. FEBS Lett 2004, 577(3):439-445.

15. Chiche J, Ilc K, Brahimi-Horn MC, Pouyssegur J: Membrane-bound carbonic anhydrases are key $\mathrm{pH}$ regulators controlling tumor growth and cell migration. Adv Enzyme Regul 2010, 50(1):20-33.

16. Swietach $P$, Wigfield $S$, Cobden $P$, Supuran $C T$, Harris AL, Vaughan-Jones RD: Tumor-associated carbonic anhydrase 9 spatially coordinates intracellular $\mathrm{pH}$ in three-dimensional multicellular growths. J Bio/ Chem 2008, 283(29):20473-20483.

17. Svastova E, Witarski W, Csaderova L, Kosik I, Skvarkova L, Hulikova A, Zatovicova M, Barathova M, Kopacek J, Pastorek J, et al: Carbonic anhydrase IX interacts with bicarbonate transporters in lamellipodia and increases cell migration via its catalytic domain. J Biol Chem 2012, 287(5):3392-3402

18. Buchler $P$, Reber HA, Buchler M, Shrinkante S, Buchler MW, Friess $H$, Semenza GL, Hines OJ: Hypoxia-inducible factor 1 regulates vascular endothelial growth factor expression in human pancreatic cancer. Pancreas 2003, 26(1):56-64.

19. Forsythe JA, Jiang BH, lyer NV, Agani F, Leung SW, Koos RD, Semenza GL: Activation of vascular endothelial growth factor gene transcription by hypoxia-inducible factor 1. Mol Cell Biol 1996, 16(9):4604-4613.

20. Wan J, Chai H, Yu Z, Ge W, Kang N, Xia W, Che Y: HIF-1a effects on angiogenic potential in human small cell lung carcinoma. J Exp Clin Cancer Res 2011, 30(1):77.

21. Brahimi-Horn MC, Bellot G, Pouyssegur J: Hypoxia and energetic tumour metabolism. Curr Opin Genet Dev 2011, 21(1):67-72.

22. Lum JJ, Bui T, Gruber M, Gordan JD, DeBerardinis RJ, Covello KL, Simon MC Thompson CB: The transcription factor HIF-1alpha plays a critical role in the growth factor-dependent regulation of both aerobic and anaerobic glycolysis. Genes Dev 2007, 21(9):1037-1049.

23. Zhang H, Gao P, Fukuda R, Kumar G, Krishnamachary B, Zeller Kl, Dang CV, Semenza GL: HIF-1 inhibits mitochondrial biogenesis and cellular respiration in VHL-deficient renal cell carcinoma by repression of C-MYC activity. Cancer Cell 2007, 11(5):407-420.

24. Marin-Hernandez A, Gallardo-Perez JC, Ralph SJ, Rodriguez-Enriquez S, Moreno-Sanchez R: HIF-1alpha modulates energy metabolism in cancer cells by inducing over-expression of specific glycolytic isoforms. Mini Rev Med Chem 2009, 9(9):1084-1101.

25. Semenza GL: Defining the role of hypoxia-inducible factor 1 in cancer biology and therapeutics. Oncogene 2010, 29(5):625-634

26. Rohwer N, Cramer T: Hypoxia-mediated drug resistance: novel insights on the functional interaction of HIFs and cell death pathways. Drug Resist Updat 2011, 14(3):191-201.

27. Riley $T$, Sontag $E$, Chen $P$, Levine A: Transcriptional control of human p53-regulated genes. Nat Rev Mol Cell Biol 2008, 9(5):402-412.

28. Green DR, Kroemer G: Cytoplasmic functions of the tumour suppressor p53. Nature 2009, 458(7242):1127-1130.

29. Feng $Z$, Levine AJ: The regulation of energy metabolism and the IGF-1 /mTOR pathways by the p53 protein. Trends Cell Biol 2010, 20(7):427-434

30. Wu X, Bayle JH, Olson D, Levine AJ: The p53-mdm-2 autoregulatory feedback loop. Genes Dev 1993, 7(7A):1126-1132.

31. Prives C: Signaling to p53: breaking the MDM2-p53 circuit. Cell 1998, 95(1):5-8.

32. Chen L, Li Z, Zwolinska AK, Smith MA, Cross B, Koomen J, Yuan Z-M, Jenuwein T, Marine J-C, Wright KL, et al: MDM2 Recruitment of lysine methyltransferases regulates p53 transcriptional output. EMBO J 2010, 29(15):2538-2552.

33. Candeias MM, Malbert-Colas L, Powell DJ, Daskalogianni C, Maslon MM, Naski N, Bourougaa K, Calvo F, Fahraeus R: P53 MRNA controls p53 activity by managing Mdm2 functions. Nat Cell Biol 2008, 10(9):1098-1105.

34. Gajjar M, Candeias MM, Malbert-Colas L, Mazars A, Fujita J, Olivares-Illana V, Fahraeus R: The p53 mRNA-Mdm2 interaction controls Mdm2 nuclear trafficking and is required for p53 activation following DNA damage. Cancer Cell 2012, 21(1):25-35.

35. Feng $Z$, Zhang $H$, Levine $A J$, Jin S: The coordinate regulation of the $\mathrm{p} 53$ and mTOR pathways in cells. Proc Natl Acad Sci USA 2005, 102(23):8204-8209.

36. Sen N, Satija YK, Das S: p53 and metabolism: old player in a new game. Transcription 2012, 3(3):119-123.

37. Hublarova P, Greplova K, Holcakova J, Vojtesek B, Hrstka R: Switching p53dependent growth arrest to apoptosis via the inhibition of DNA damage-activated kinases. Cell Mol Biol Lett 2010, 15(3):473-484.

38. Chen BP, Wolfgang CD, Hai T: Analysis of ATF3, a transcription factor induced by physiological stresses and modulated by gadd153/Chop10. Mol Cell Biol 1996, 16(3):1157-1168.

39. Tanaka Y, Nakamura A, Morioka MS, Inoue S, Tamamori-Adachi M, Yamada K, Taketani K, Kawauchi J, Tanaka-Okamoto M, Miyoshi J, et al: Systems analysis of ATF3 in stress response and cancer reveals opposing effects on pro-apoptotic genes in p53 pathway. PLoS One 2011, 6(10):e26848.

40. Zhang X-P, Liu F, Wang W: Two-phase dynamics of p53 in the DNA damage response. Proc Natl Acad Sci USA 2011, 108(22):8990-8995.

41. Takekawa M, Adachi M, Nakahata A, Nakayama I, Itoh F, Tsukuda H, Taya Y, Imai K: p53-Inducible wip1 phosphatase mediates a negative feedback regulation of p38 MAPK-p53 signaling in response to UV radiation. EMBO J 2000, 19(23):6517-6526.

42. Tasdemir E, Maiuri MC, Galluzzi L, Vitale I, Djavaheri-Mergny M, D'Amelio M, Criollo A, Morselli E, Zhu C, Harper F, et al: Regulation of autophagy by cytoplasmic p53. Nat Cell Biol 2008, 10(6):676-687.

43. Prives C, Hall PA: The p53 pathway. J Pathol 1999, 187(1):112-126.

44. Muller P, Hrstka R, Coomber D, Lane DP, Vojtesek B: Chaperone-dependent stabilization and degradation of p53 mutants. Oncogene 2008, 27(24):3371-3383.

45. Royds JA, Dower SK, Qwarnstrom EE, Lewis CE: Response of tumour cells to hypoxia: role of p53 and NFkB. Mol Pathol 1998, 51(2):55-61.

46. Graeber TG, Peterson JF, Tsai M, Monica K, Fornace AJ Jr, Giaccia AJ: Hypoxia induces accumulation of $\mathrm{p} 53$ protein, but activation of a G1phase checkpoint by low-oxygen conditions is independent of p53 status. Mol Cell Biol 1994, 14(9):6264-6277.

47. Hammond EM, Denko NC, Dorie MJ, Abraham RT, Giaccia AJ: Hypoxia links ATR and p53 through replication arrest. Mol Cell Biol 2002, 22(6):1834-1843.

48. Hubert A, Paris S, Piret JP, Ninane N, Raes M, Michiels C: Casein kinase 2 inhibition decreases hypoxia-inducible factor-1 activity under hypoxia through elevated p53 protein level. J Cell Sci 2006, 119(Pt 16):3351-3362.

49. Zhang L, Hill RP: Hypoxia enhances metastatic efficiency by up-regulating Mdm2 in KHT cells and increasing resistance to apoptosis. Cancer Res 2004, 64(12):4180-4189.

50. Wouters A, Pauwels B, Lambrechts HAJ, Pattyn GGO, Ides J, Baay M, Meijnders P, Dewilde S, Vermorken JB, Lardon F: Chemoradiation interactions under reduced oxygen conditions: cellular characteristics of an in vitro model. Cancer Lett 2009, 286(2):180-188.

51. Sermeus A, Michiels C: Reciprocal influence of the $p 53$ and the hypoxic pathways. Cell Death Dis 2011, 2:e164.

52. Suzuki H, Tomida A, Tsuruo T: Dephosphorylated hypoxia-inducible factor 1 alpha as a mediator of p53-dependent apoptosis during hypoxia. Oncogene 2001, 20(41):5779-5788.

53. An WG, Kanekal M, Simon MC, Maltepe E, Blagosklonny MV, Neckers LM: Stabilization of wild-type p53 by hypoxia-inducible factor 1 alpha. Nature 1998, 392(6674):405-408.

54. Achison M, Hupp TR: Hypoxia attenuates the $\mathrm{p} 53$ response to cellular damage. Oncogene 2003, 22(22):3431-3440.

55. Cosse J-P, Sermeus A, Vannuvel K, Ninane N, Raes M, Michiels C: Differential effects of hypoxia on etoposide-induced apoptosis according to the cancer cell lines. Mol Cancer 2007, 6:61.

56. Kaluzova M, Kaluz S, Lerman MI, Stanbridge EJ: DNA damage is a prerequisite for $\mathrm{p} 53$-mediated proteasomal degradation of HIF-1alpha in 
hypoxic cells and downregulation of the hypoxia marker carbonic anhydrase IX. Mol Cell Biol 2004, 24(13):5757-5766.

57. Nardinocchi L, Puca R, D'Orazi G: HIF-1 alpha antagonizes p53-mediated apoptosis by triggering HIPK2 degradation. Aging-Us 2011, 3(1):33-43.

58. D'Orazi G, Cecchinelli B, Bruno T, Manni I, Higashimoto Y, Saito S, Gostissa M, Coen S, Marchetti A, Del Sal G, et al: Homeodomain-interacting protein kinase-2 phosphorylates p53 at Ser 46 and mediates apoptosis. Nat Cell Biol 2002, 4(1):11-19.

59. Nardinocchi L, Puca R, Sacchi A, Rechavi G, Givol D, D'Orazi G: Targeting hypoxia in cancer cells by restoring homeodomain interacting proteinkinase 2 and p53 activity and suppressing HIF-1 alpha. PLoS One 2009, 4(8):e6819.

60. Gogna R, Madan E, Kuppusamy P, Pati U: Chaperoning of mutant p53 protein by wild-type $\mathrm{p} 53$ protein causes hypoxic tumor regression. J Biol Chem 2012, 287(4):2907-2914.

61. Madan E, Gogna R, Pati U: p53 Ser15 Phosphorylation disrupts the p53-RPA70 complex and induces RPA70-mediated DNA repair in hypoxia. Biochem J 2012, 443(3):811-820.

62. Thomas DD, Espey MG, Ridnour LA, Hofseth LJ, Mancardi D, Harris CC, Wink DA: Hypoxic inducible factor 1alpha, extracellular signalregulated kinase, and $\mathrm{p} 53$ are regulated by distinct threshold concentrations of nitric oxide. Proc Natl Acad Sci USA 2004, 101(24):8894-8899.

63. Warburg O: On the origin of cancer cells. Science 1956, 123(3191):309-314.

64. Yalcin A, Telang S, Clem B, Chesney J: Regulation of glucose metabolism by 6-phosphofructo-2-kinase/fructose-2,6-bisphosphatases in cancer. Exp Mol Pathol 2009, 86(3):174-179.

65. Vander Heiden MG, Cantley LC, Thompson CB: Understanding the Warburg effect: the metabolic requirements of cell proliferation. Science 2009, 324(5930):1029-1033.

66. Hsu PP, Sabatini DM: Cancer cell metabolism: Warburg and beyond. Cell 2008, 134(5):703-707.

67. Ferguson EC, Rathmell JC: New roles for pyruvate kinase M2: working out the Warburg effect. Trends Biochem Sci 2008, 33(8):359-362.

68. Hommes FA, Everts RS: Particulate and free hexokinase in fetal rat liver. Biol Neonate 1978, 33(3-4):193-200.

69. Kuhajda FP: Fatty-acid synthase and human cancer: new perspectives on its role in tumor biology. Nutrition 2000, 16(3):202-208.

70. Migita T, Narita T, Nomura K, Miyagi E, Inazuka F, Matsuura M, Ushijima M, Mashima T, Seimiya H, Satoh Y, et al: ATP citrate lyase: activation and therapeutic implications in non-small cell lung cancer. Cancer Res 2008, 68(20):8547-8554.

71. Yan H, Parsons DW, Jin G, McLendon R, Rasheed BA, Yuan W, Kos I, BatinicHaberle I, Jones S, Riggins GJ, et al: IDH1 and IDH2 mutations in gliomas. N Engl J Med 2009, 360(8):765-773.

72. Young CD, Anderson SM: Sugar and fat - that's where it's at: metabolic changes in tumors. Breast Cancer Res 2008, 10(1):202.

73. Mentis A-FA, Kararizou E: Metabolism and cancer: an up-to-date review of a mutual connection. Asian Pac J Cancer Prev 2010, 11(6):1437-1444.

74. Israel M, Schwartz L: The metabolic advantage of tumor cells. Mol Cancer 2011, 10:70.

75. Munoz-Pinedo C, El Mjiyad N, Ricci JE: Cancer metabolism: current perspectives and future directions. Cell Death Dis 2012, 3:e248.

76. Guccini I, Serio D, Condo I, Rufini A, Tomassini B, Mangiola A, Maira G, Anile $C$, Fina $D$, Pallone $F$, et al: Frataxin participates to the hypoxia-induced response in tumors. Cell Death Dis 2011, 2:e123.

77. Selak MA, Armour SM, Mackenzie ED, Boulahbel H, Watson DG, Mansfield KD, Pan Y, Simon MC, Thompson CB, Gottlieb E: Succinate links TCA cycle dysfunction to oncogenesis by inhibiting HIF-alpha prolyl hydroxylase. Cancer Cell 2005, 7(1):77-85.

78. Kawauchi K, Araki K, Tobiume K, Tanaka N: p53 Regulates glucose metabolism through an IKK-NF-kappaB pathway and inhibits cell transformation. Nat Cell Biol 2008, 10(5):611-618.

79. Wanka C, Brucker DP, BV/\$hr O, Ronellenfitsch M, Weller M, Steinbach $J P$, Rieger J: Synthesis of cytochrome c oxidase 2: a p53-dependent metabolic regulator that promotes respiratory function and protects glioma and colon cancer cells from hypoxia-induced cell death. Oncogene 2012, 31(33):3764-3776.

80. White E, Karp C, Strohecker AM, Guo YX, Mathew R: Role of autophagy in suppression of inflammation and cancer. Curr Opin Cell Biol 2010, 22(2):212-217
81. Mazure NM, Pouyssegur J: Hypoxia-induced autophagy: cell death or cell survival? Curr Opin Cell Biol 2010, 22(2):177-180.

82. Martinez-Outschoorn UE, Trimmer C, Lin Z, Whitaker-Menezes D, Chiavarina B, Zhou J, Wang CW, Pavlides S, Martinez-Cantarin MP, Capozza F, et al: Autophagy in cancer associated fibroblasts promotes tumor cell survival role of hypoxia, HIF1 induction and NF kappa B activation in the tumor stromal microenvironment. Cell Cycle 2010, 9(17):3515-3533.

83. Crighton D, Wilkinson S, O'Prey J, Syed N, Smith P, Harrison PR, Gasco M, Garrone O, Crook T, Ryan KM: DRAM, a p53-induced modulator of autophagy, is critical for apoptosis. Cell 2006, 126(1):121-134.

84. Xu-Monette ZY, Young KH: The TP53 tumor suppressor and autophagy in malignant lymphoma. Autophagy 2012, 8(5):842-845.

85. Boya P, Gonzalez-Polo RA, Casares N, Perfettini JL, Dessen P, Larochette N, Metivier D, Meley D, Souquere S, Yoshimori T, et al: Inhibition of macroautophagy triggers apoptosis. Mol Cell Biol 2005, 25(3):1025-1040.

86. Tasdemir E, Maiuri MC, Galluzzi L, Vitale I, Djavaheri-Mergny M, D'Amelio M, Criollo A, Morselli E, Zhu CL, Harper F, et al: Regulation of autophagy by cytoplasmic p53. Nat Cell Biol 2008, 10(6):676-687.

87. Naves T, Jawhari S, Jauberteau MO, Ratinaud MH, Verdier M: Autophagy takes place in mutated p53 neuroblastoma cells in response to hypoxia mimetic CoCl2. Biochem Pharmacol 2013, 85(8):1153-1161.

88. Leontieva OV, Natarajan V, Demidenko ZN, Burdelya LG, Gudkov AV, Blagosklonny MV: Hypoxia suppresses conversion from proliferative arrest to cellular senescence. Proc Natl Acad Sci USA 2012, 109(33):13314-13318.

89. Dos Santos F, Andrade PZ, Boura JS, Abecasis MM, da Silva CL, Cabral JM: Ex vivo expansion of human mesenchymal stem cells: a more effective cell proliferation kinetics and metabolism under hypoxia. J Cell Physiol 2010, 223(1):27-35.

90. Tsai CC, Chen YJ, Yew TL, Chen LL, Wang JY, Chiu CH, Hung SC: Hypoxia inhibits senescence and maintains mesenchymal stem cell properties through down-regulation of E2A-p21 by HIF-TWIST. Blood 2011, 117(2):459-469.

91. Welford SM, Giaccia AJ: Hypoxia and senescence: the impact of oxygenation on tumor suppression. Mol Cancer Res 2011, 9(5):538-544.

92. Chen Q, Fischer A, Reagan JD, Yan $L$, Ames BN: Oxidative DNA damage and senescence of human diploid fibroblast cells. Proc Natl Acad Sci USA 1995, 92(10):4337-4341.

93. Capparelli C, Whitaker-Menezes D, Guido C, Balliet R, Pestell TG, Howell A, Sneddon S, Pestell RG, Martinez-Outschoorn U, Lisanti MP, et al: CTGF drives autophagy, glycolysis and senescence in cancer-associated fibroblasts via HIF1 activation, metabolically promoting tumor growth. Cell Cycle 2012, 11(12):2272-2284.

94. Welford SM, Dorie MJ, Li X, Haase VH, Giaccia AJ: Renal oxygenation suppresses VHL loss-induced senescence that is caused by increased sensitivity to oxidative stress. Mol Cell Biol 2010, 30(19):4595-4603.

95. Dulic V: Senescence regulation by mTOR. Methods Mol Biol 2013, 965:15-35.

96. Hasty P, Sharp ZD, Curiel TJ, Campisi J: mTORC1 and p53: clash of the gods? Cell Cycle 2013, 12(1):20-25.

97. Rufini A, Tucci P, Celardo I, Melino G: Senescence and aging: the critical roles of p53. Oncogene 2013. doi:10.1038/onc.2012.640. Epub ahead of print.

98. Blagosklonny MV: Tumor suppression by $\mathrm{p} 53$ without apoptosis and senescence: conundrum or rapalog-like gerosuppression? Aging 2012, 4(7):450-455.

99. Ousset M, Bouquet F, Fallone F, Biard D, Dray C, Valet P, Salles B, Muller C: Loss of ATM positively regulates the expression of hypoxia inducible factor 1 (HIF-1) through oxidative stress: role in the physiopathology of the disease. Cell Cycle 2010, 9(14):2814-2822.

100. Cam H, Easton JB, High A, Houghton PJ: mTORC1 Signaling under hypoxic conditions is controlled by ATM-dependent phosphorylation of HIF-1a. Mol Cell 2010, 40(4):509-520.

101. Freedman SJ, Sun Z-YJ, Poy F, Kung AL, Livingston DM, Wagner G, Eck MJ: Structural basis for recruitment of $\mathrm{CBP} / \mathrm{p} 300$ by hypoxia-inducible factor1 alpha. Proc Natl Acad Sci U S A 2002, 99(8):5367-5372.

102. Xenaki G, Ontikatze T, Rajendran R, Stratford IJ, Dive C, Krstic-Demonacos M, Demonacos C: PCAF is an HIF-1alpha cofactor that regulates p53 transcriptional activity in hypoxia. Oncogene 2008, 27(44):5785-5796.

103. Roe JS, Kim H, Lee SM, Kim ST, Cho EJ, Youn HD: p53 Stabilization and transactivation by a von hippel-lindau protein. Mol Cell 2006, 22(3):395-405 
104. Pelletier J, Dayan F, Durivault J, Ilc K, Pecou E, Pouyssegur J, Mazure NM: The asparaginyl hydroxylase factor-inhibiting HIF is essential for tumor growth through suppression of the p53-p21 axis. Oncogene 2012, 31(24):2989-3001.

105. Ashcroft M, Taya Y, Vousden KH: Stress signals utilize multiple pathways to stabilize p53. Mol Cell Biol 2000, 20(9):3224-3233.

106. Koumenis C, Alarcon R, Hammond E, Sutphin P, Hoffman W, Murphy M, Derr J, Taya Y, Lowe SW, Kastan M, et al: Regulation of p53 by hypoxia: dissociation of transcriptional repression and apoptosis from p53 dependent transactivation. Mol Cell Biol 2001, 21(4):1297-1310.

107. Koshikawa N, Maejima C, Miyazaki K, Nakagawara A, Takenaga K: Hypoxia selects for high-metastatic Lewis lung carcinoma cells overexpressing Mcl-1 and exhibiting reduced apoptotic potential in solid tumors. Oncogene 2006, 25(6):917-928.

108. Hockel M, Schlenger K, Aral B, Mitze M, Schaffer U, Vaupel P: Association between tumor hypoxia and malignant progression in advanced cancer of the uterine cervix. Cancer Res 1996, 56(19):4509-4515.

109. Cleven AHG, van Engeland M, Wouters BG, de Bruine AP: Stromal expression of hypoxia regulated proteins is an adverse prognostic factor in colorectal carcinomas. Cell Oncol 2007, 29(3):229-240.

110. Cleven AH, Wouters BG, Schutte B, Spiertz AJ, van Engeland M, de Bruine AP: Poorer outcome in stromal HIF-2 alpha- and CA9-positive colorectal adenocarcinomas is associated with wild-type TP53 but not with BNIP3 promoter hypermethylation or apoptosis. Br J Cancer 2008, 99(5):727-733.

111. O'Toole D, Couvelard A, Rebours V, Zappa M, Hentic O, Hammel P, Levy P, Bedossa P, Raymond E, Ruszniewski P: Molecular markers associated with response to chemotherapy in gastro-entero-pancreatic neuroendocrine tumors. Endocr Relat Cancer 2010, 17(4):847-856.

112. Tan EY, Yan M, Campo L, Han C, Takano E, Turley H, Candiloro I, Pezzella F, Gatter KC, Millar EK, et al: The key hypoxia regulated gene CAIX is upregulated in basal-like breast tumours and is associated with resistance to chemotherapy. Br J Cancer 2009, 100(2):405-411.

113. Maeda K, Chung YS, Ogawa Y, Takatsuka S, Kang SM, Ogawa M, Sawada T, Sowa M: Prognostic value of vascular endothelial growth factor expression in gastric carcinoma. Cancer 1996, 77(5):858-863.

114. Andersen S, Donnem T, Stenvold H, Al-Saad S, Al-Shibli K, Busund L-T, Bremnes RM: Overexpression of the HIF hydroxylases PHD1, PHD2, PHD3 and FIH are individually and collectively unfavorable prognosticators for NSCLC survival. PLoS One 2011, 6(8):e23847.

115. Henze A-T, Riedel J, Diem T, Wenner J, Flamme I, Pouyseggur J, Plate KH, Acker T: Prolyl hydroxylases 2 and 3 act in gliomas as protective negative feedback regulators of hypoxia-inducible factors. Cancer Res 2010, 70(1):357-366.

116. Baas IO, Hruban RH, Offerhaus GJ: Clinical applications of detecting dysfunctional p53 tumor suppressor protein. Histol Histopathol 1999, 14(1):279-284.

117. Khromova NV, Kopnin PB, Stepanova EV, Agapova LS, Kopnin BP: p53 hotspot mutants increase tumor vascularization via ROS-mediated activation of the HIF1/VEGF-a pathway. Cancer Lett 2009, 276(2):143-151.

118. Baba Y, Nosho K, Shima K, Irahara N, Chan AT, Meyerhardt JA, Chung DC, Giovannucci EL, Fuchs CS, Ogino S: HIF1A Overexpression is associated with poor prognosis in a cohort of 731 colorectal cancers. Am J Pathol 2010, 176(5):2292-2301.

119. Fondevila C, Metges JP, Fuster J, Grau JJ, Palacín A, Castells A, Volant A, Pera $M:$ p53 and VEGF expression are independent predictors of tumour recurrence and survival following curative resection of gastric cancer. Br J Cancer 2004, 90(1):206-215.

120. Oh SY, Kwon H-C, Kim S-H, Jang JS, Kim MC, Kim KH, Han J-Y, Kim CO, Kim $\mathrm{S}-\mathrm{J}$, Jeong J-S, et al: Clinicopathologic significance of HIF-1alpha, p53, and VEGF expression and preoperative serum VEGF level in gastric cancer. BMC Cancer 2008, 8:123.

121. Gryko M, Pryczynicz A, Guzinska-Ustymowicz K, Kamocki Z, Zareba K, Kemona A, Kedra B: Immunohistochemical assessment of apoptosisassociated proteins: p53, Bcl-xL, Bax and Bak in gastric cancer cells in correlation with clinical and pathomorphological factors. Adv Med Sci 2012, 57(1):77-83

122. Wang J, Biju MP, Wang M-H, Haase VH, Dong Z: Cytoprotective effects of hypoxia against cisplatin-induced tubular cell apoptosis: involvement of mitochondrial inhibition and p53 suppression. J Am Soc Nephrol 2006, 17(7):1875-1885.
123. Brown JM: Exploiting the hypoxic cancer cell: mechanisms and therapeutic strategies. Mol Med Today 2000, 6(4):157-162.

124. Fardel O, Lecureur V, Guillouzo A: The P-glycoprotein multidrug transporter. Gen Pharmacol 1996, 27(8):1283-1291.

125. Tiwari AK, Sodani K, Dai C-L, Ashby CR Jr, Chen Z-S: Revisiting the ABCs of multidrug resistance in cancer chemotherapy. Curr Pharm Biotechnol 2011, 12(4):570-594.

126. Doublier S, Belisario DC, Polimeni M, Annaratone L, Riganti C, Allia E, Ghigo D, Bosia A, Sapino A: HIF-1 activation induces doxorubicin resistance in MCF7 3-D spheroids via P-glycoprotein expression: a potential model of the chemo-resistance of invasive micropapillary carcinoma of the breast. BMC Cancer 2012, 12:4

doi:10.1186/1476-4598-12-93

Cite this article as: Obacz et al.: Cross-talk between HIF and p53 as mediators of molecular responses to physiological and genotoxic stresses. Molecular Cancer 2013 12:93.

\section{Submit your next manuscript to BioMed Central and take full advantage of:}

- Convenient online submission

- Thorough peer review

- No space constraints or color figure charges

- Immediate publication on acceptance

- Inclusion in PubMed, CAS, Scopus and Google Scholar

- Research which is freely available for redistribution
C Biomed Central 